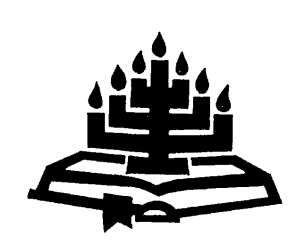

\title{
Die waarde van menswaardigheid in die bioetiek
}

\author{
A.L. Rheeder \\ Skool vir Kerkwetenskappe \\ Potchefstroomkampus \\ Noordwes-Universiteit \\ POTCHEFSTROOM \\ E-pos: corriaan1@942.co.za
}

\begin{abstract}
The worth of human dignity in bioethics

Bioethicists and jurists put forward that the notion of "human dignity" adds nothing to the field of bioethics and is essentially a meaningless term. Against this presupposition the view is put forward that the notion of "human dignity" belongs to the heart of the Bible and can therefore be used as a valuable notion in bioethics. Human dignity is founded in the fact that man is created in the image of God. The fact that man is created in God's image, and therefore has human dignity, undoubtedly has implications for bioethics. Human dignity by and towards man in bioethics has the meaning that one must strive for the healing of disease; that man must act and be treated as a psychosomatic unit; that reproduction may occur exclusively within marriage; and that all human life has to be maximally protected. Where the aforementioned does not occur, Godgiven human dignity is impinged upon.
\end{abstract}

\section{Opsomming}

\section{Die waarde van menswaardigheid in die bioetiek}

Daar word vandag deur bioetici en juriste aangevoer dat die begrip "menswaardigheid" geen bedrae lewer tot die bioetiek nie en in wese 'n nuttelose begrip is. Teenoor hierdie vooronderstelling word uitgegaan van die standpunt dat die begrip "menswaardigheid" tot die hart van die Bybel behoort en daarom as 'n vrugbare begrip in die bioetiek gebruik kan word. Menswaardigheid word gefundeer in die feit dat die mens na die beeld van God geskape is. Die feit dat die mens as beeld van God geskape is en dus menswaardig is, het ongetwyfeld implikasies vir die bioetiek. Menswaardigheid deur en teenoor 
die mens binne die bioetiek beteken dat genesing van siekte nagestreef moet word; dat die mens as psigosomatiese eenheid moet handel en behandel word; dat voortplanting eksklusief vanuit die huwelik mag plaasvind; en dat alle menslike lewe maksimaal beskerm moet word. Waar laasgenoemde nie gebeur nie, word die godgegewe waarde van die mens aangetas.

\section{Inleiding}

Hierdie artikel wil aandag gee aan die fundering, betekenis en relevansie van die begrip menswaardigheid spesifiek vir die gereformeerde bioetiek. Bioetiek kan gedefinieer word as die beoordeling van etiese vraagstukke in mediese navorsing en die behandeling van pasiënte, waar veral die gebruik van gevorderde tegnologie betrokke is (Christoffersen, 1995:2-8). Daar is vandag etici en veral bioetici wat van mening is dat die begrip menswaardigheid geen betekenisinhoud het nie en daarom eintlik as oorbodig beskou moet word. Die bioetiek kan vry van enige nadeel sonder hierdie etiese begrip funksioneer (Davis, 2008:19). Volgens Churchland (2008: 101) word daar in dié begrip vergeefs gesoek na betekenis vir die bioetiek. Die begrip ontbreek aan konseptuele duidelikheid (Sulmasy, 2008:469). Sommige etici is van mening dat daar na 'n beter begrip in die bioetiek gesoek moet word (Schulman, 2008:5). Macklin (2003:1419-1420) is oortuig dat die begrip "respek vir die persoon" of "respek vir outonomiteit" die gedagte van menswaardigheid moet vervang en as bioetiese of medies-etiese begrip moet dien (Davis, 2008:20; Schulman, 2008:14). Eintlik beteken menswaardigheid niks meer as outonomiteit nie (Gelernter, 2008:387; Meilaender, 2008b:273-275). Volgens Macklin gebruik bioetici die begrip menswaardigheid as 'n tipe slagspreuk, maar bedoel niks meer as respek vir die mens of respek vir die outonomie van die mens nie.

Hierdie artikel het die navorsing ten doel of die begrip van menswaardigheid as 'n bruikbare begrip in die bioetiek kan funksioneer en of respek vir die persoon en sy outonomiteit moontlik 'n voldoende of selfs beter begrip is. Die wyse waarop aan die doel uitvoering gegee sal word, is om vanuit 'n gereformeerde teologiesetiese hoek aandag te gee aan die inhoud van die begrip menswaardigheid. Hierdie artikel word aangebied as 'n poging tot die uitbouing van 'n gereformeerd-teoreties konseptuele verklaring van menswaardigheid vir die bioetiek. 


\section{Menswaardigheid - 'n nuttelose begrip}

\subsection{Meerduidige begrip}

Daar bestaan hoofsaaklik twee redes waarom die begrip menswaardigheid van konseptuele onduidelikheid beskuldig word en daarom as 'n nuttelose begrip in die bioetiek beskou word.

Die feit dat menswaardigheid 'n nuttelose begrip vir gebruik in die bioetiek beskou word, word geïllustreer deur die pynlike realiteit dat etici die begrip inspan as argument vir en teen 'n bepaalde etiese probleem of handeling (Gelernter, 2008:387; Kass, 2008:297, 306; Schulman, 2008:4). 'n Persoon word byvoorbeeld gediagnoseer met Alzheimer-siekte en mag nog redelik goed praat en selfs tennis speel, maar kan nie meer 'n boek lees nie. Hy weet dat hy nog tien jaar kan lewe, maar is ook bewus van die werklikheid dat in die laaste fase van sy lewe, wat etlike jare kan duur, hy nie in staat gaan wees om iemand te herken of met iemand te kommunikeer nie. Hy gaan moontlik net in 'n bondel in sy bed lê en vegeteer. Die vooruitsig van so 'n lewe mag deur die pasiënt as vernederend (onmenswaardig) en weersinswekkend beskou word. Deur sy dood met geassisteerde selfmoord te verhaas, verminder hy sy eie hartseer en lyding asook die hartseer van sy familie. Voorstanders vir die wettiging van geassisteerde selfmoord beroep hulle op die feit dat dit aan die mens die moontlikheid van 'n menswaardige dood (death with dignity) bied. Teenstanders van die wettiging van geassisteerde selfmoord voer egter weer aan dat so 'n handeling die menswaardigheid van alle betrokkenes aantas (Sulmasy, 2008:469). 'n Derde antwoord meen dat respek vir menswaardigheid van die mens die keuse aan so 'n persoon oorlaat, ongeag wat hy mag kies. Let op dat al drie antwoorde hulle beroep op menswaardigheid as argument (Schulman, 2008:4; Shultziner, 2003:16). ${ }^{1}$

\subsection{Begrip sonder inhoud}

'n Volgende probleem verbonde aan die gebruik van die begrip menswaardigheid in die bioetiek word geïllustreer deur die realiteit dat baie moderne internasionale menseregtedokumente dié begrip gereeld gebruik sonder om dit te omskryf. Hier word gedink aan die Charter of the United Nations (1945), Universal declaration of

1 "Little wonder, then, that some bioethicists are inclined to wash their hands of dignity entirely, in favor of clearer and less ambiguous ethical concepts." (Schulman, 2008:5.) 
human rights (1948) en Basic law of Germany (1948). Ongeveer 37 nasionale konstitusies wat die begrip menswaardigheid geratifiseer het, doen dit sonder om die begrip te verduidelik (Schulman, 2008: 12-13). Al hierdie dokumente erken dat menswaardigheid die fondament van menseregte en pligte (en dus etiek) vorm, sonder dat die betekenis, inhoud en fundering van die begrip gespesifiseer word (Shultziner, 2003:2). 'n Voorbeeld binne die konteks van die bioetiek is die feit dat UNESCO (2005) 2 onlangs die Universal declaration on bioethics and human rights voorlopig aanvaar het. In hierdie dokumente word elf keer na menswaardigheid verwys sonder dat die begrip verduidelik of omskryf word. Die argument is dat indien "we are content to regard human dignity as nothing more than an unspecified 'Factor $X$ ' in virtue of which we are obliged to treat all persons with respect, then some bioethicist have wondered why we should bother invoking it at all. Why not dispense with dignity and simply spell out precisely what 'respect for person' demands of us" (Schulman, 2008:13-14). In die lig van bogenoemde beredenering kan Churchland (2008:101) sê:

... then all the variation, ambiguity, vagueness, and openendedness inherent in ordinary usage of 'human dignity' is immediately laid bare.

In die lig van die voorafgaande beredenering, is Sulmasy (2008:469) korrek as hy meen dat die begrip menswaardigheid in die bioetiek verheldering en verduideliking benodig.

\section{Menswaardigheid - 'n waardevolle begrip}

\subsection{Bybelse idee van menswaardigheid}

\subsubsection{Inleidend}

Teenoor die voorafgaande word in hierdie volgende afdeling geredeneer dat die begrip menswaardigheid van uiterste belang is vir die bioetiek (Kass, 2008:298): "Today, human dignity is of paramount importance especially in matters bioethical." Ook Grogan (1995:477) is van mening dat die mens as beeld van God en met sy gepaardgaande menswaardigheid as 'n belangrike oorweging in bioetiese probleme hanteer moet word (vgl. Østnor et al., 1995:29-30). In 'n resente ensikliek van die Rooms-Katolieke Kerk ten opsigte van bioetiek word die volgende gesê:

2 United Nations Educational, Scientific and Cultural Organization. 
The dignity of a person must be recognized in every human being from conception to natural death. This fundamental principle expresses a great yes to human life and must be at the center of ethical reflection on biomedical research, which has an ever greater importance in today's world. (RKK, 2008; vgl. ook Sulmasy, 2008:484.)

Kass (2008:297) is van oordeel dat hierdie problematiek met betrekking tot die begrip erken moet word. Meilaender (2008a:122) wat ook die dilemma rondom die begrip menswaardigheid erken, meen dit bied geen verskoning om nie hierdie begrip te gebruik nie. Inteendeel, die waarheid dat die saak van menswaardigheid tot die hart van die Bybelse boodskap behoort (Vorster, 2007:18), begin al in die rigting dui dat die begrip tog van waarde kan wees. Dit is inderdaad 'n universeel erkende (Bybelse) begrip waarvan die betekenis en toepassing daarvan in die bioetiek saam bepeins moet word:

At the same time, human history has also shown real progress in the understanding and recognition of the value and dignity of every person as the foundation of the rights and ethical imperatives by which human society has been, and continues to be structured. (RKK, 2008.)

In hierdie afdeling sal opsommend bepaal word wat die gereformeerde teologie as bron gebruik en tweedens sal nader aangedui word presies wat menswaardigheid beteken, asook 'n kursoriese toepassing en waardebepaling daarvan in die bioetiek.

\subsubsection{Bron van bepaling}

Churchland (2008:101-102) is van oordeel dat daar geen finale en onaanvegbare waarheidsbron in die bioetiek bestaan waaruit presies bepaal kan word wat menswaardigheid beteken nie. Die enigste werkbare bron is "fair-minded" kompromieë van logiese denke. Hierteenoor is die uitgangspunt van hierdie artikel die Bybel as die Woord van God (1 Tess. 2:13; vgl. Van Wyk, 1991:22; De Bruyn, 1993:2) waarin sy wil gevind word (Ps. 119:105). God maak bekend wat goed en kwaad is (Miga 6:8).

Verskeie wetenskaplikes gaan uit van die standpunt dat die skeppingsleer een van die vernaamste teologiese leerstukke is wat as bron vir die Christelike etiek dien (Holmes, 1995:268; Østnor et al., 1995:12, 30; Wright, 1995:49). Etiese voorskrifte moet teologies gedryf word (Brown, 1995:238). Die etiek put uit die waarheid dat God geskep het en dat dit wat Hy geskep het, voor die sondeval goed 
genoem word (RKK, 2008). Die huwelik en seksualiteit is die manifestasie van God se goeie skeppingsdade (Østnor et al., 1995:18). Omdat God dit wat Hy geskep het, goed noem, vind ons dat die Here Jesus self na die skepping (orde) verwys, om dit wat reg en verkeerd is, te fundeer (Matt. 6:19-34; 19:3-12). Paulus doen dieselfde (1 Tim. 4:1-5; Rom. 1:18-2:16; Holmes, 1995:268). Die skeppingsnarratief (Gen. 1 en 2) is van besondere waarde omdat menswaardigheid in die skeppingsleer gefundeer is en spesifiek binne die leerstuk dat die mens na die beeld van God geskep is (vgl. ook Higginson, 1995:97; Douma, 1997:44). Die mens as beeld van God vorm die onderbou van die hele Ou Testament (Vorster, 2008:12122) en ipso facto van die hele Skrif. "If you want to understand how God looks at biotech, get into the beginning of the book Genesis and stay there." (Tada \& Cameron, 2006:50.) In die begin het God die mens na sy beeld geskape (Gen. 1 en 2) en in die geskepte natuur van hierdie eerste mensepaar word God se oorspronklike wese en doel vir die mens en die huwelik afgelei (Holmes, 1995:268; Vorster, 2007:40).

\subsubsection{Mens geskape as beeld van God}

Vir tweeduisend jaar was die begrip menswaardigheid nie as 'n belangrike teologiese term beskou nie, en tot baie onlangs was dié term nooit in bioetiese beredenering gebruik nie (Sulmasy, 2008: 470). Dit het egter verander. Die term menswaardigheid kom nie in die Bybel voor nie, maar wel die saak. Die Bybel is duidelik daaroor dat God die hemel en die aarde en alles op die aarde, ook diere en plante, geskape het. God het ook die mens geskape. Op verskeie plekke in die Skrif word gelees dat God die mens na sy beeld geskape het: "Toe het God gesê: 'Kom Ons maak die mens as ons verteenwoordiger, ons beeld ...' staan in Genesis 1:26 (vgl. ook Gen. 1:27; 5:1-3; 9:5-7; Ps. 8). Die feit dat God die mens na sy beeld geskape het, bring die mens sonder twyfel in 'n besondere verband met God (Vorster, 2007:39). Die skepping is 'n geordende hiërargie waarin God gekies het om aan die mens sy beeld te verbind.

Wat beteken die begrip mens as beeld van God? Die mens as beeld beteken nie dat die mens God is nie. Volgens König (2006:61) dui die gedagte van die mens as beeld van God dat daar 'n besondere ooreenkoms tussen God en die mens is. In Genesis 5 is daar direk na mekaar twee verwysings na "beeld". Die eerste is 'n herhaling van Genesis 1 waar God die mens na sy beeld geskape het (Gen. $1: 1$ ), en direk daarna 'n verwysing na die geboorte van Adam se seun Set van wie dan gesê word: "sy beeld, een soos hyself" (Gen. 
5:3). As dit gesê word van 'n pa en 'n seun, kan 'n mens vermoed dit beteken: daar is 'n besondere ooreenkoms. Beeld van God hou dan die gedagte in dat die geskape mens soos God is. Daar is 'n besondere ooreenkoms tussen God en die mens. Dit lê natuurlik vanaf die begin opgesluit in die woorde beeld (מדל (דימות). Die Hebreeuse woord vir beeld en gelykenis druk sinonieme gedagtes uit. Volgens Grogan (1995:476) word die sinonieme vir beklemtoning gebruik, wat beteken dat God wil hê dat die geskape mens sonder twyfel homself as sy beeld sal verstaan. In die Hebreeuse woorde vir beeld lê ook die gedagte opgesluit dat die mens wat die beeld is, ook die beeld moet laat skyn, moet reflekteer of moet wees. Anders gesê, die mens moet God se eienskappe (deugde) in die wêreld verteenwoordig (O'Mathúna, 1995:202). Die mens moet God in die wêreld manifesteer (RKK, 2008). Dit is die wese van ' $n$ beeld om te vertoon; daarom moet die mens ook beeld wees. Die mens is die kopie of refleksie van die oorspronklike (Vorster, 2007:20). Om bogenoemde te verduidelik: die mens moet soos God, wat liefde is, liefde vertoon. Die mens as beeld van God moet juis die (ongelowige) mens aanspoor om die oorspronklike Beeld te leer ken.

In die Nuwe Testament is ' $n$ verskeidenheid verwysings met heelwat inhoud. Uit Efesiërs 4:243 word gesien dat die beeldwees van God as ' $n$ eksplisiete opdrag na die mens kom, naamlik tree op as beelddraers. Hier word 'n verwysing gevind na Genesis 1, maar met 'n verskil. Die Ou Testament plaas die klem op die werklikheid dat die mens die beeld van God is, terwyl die Nuwe Testament die klem daarop plaas dat die mens die beeld van God ook moet wees. Beeldskap beteken dat God aan die mens 'n sekere rol toeken: elkeen moet God se verteenwoordiger op aarde wees. Om beeld van God te wees beteken dat die mens die gedagtes, dade en gesindheid van God moet reflekteer (vgl. De Bruyn, 1993:71-72). Beeld van God is egter ook meer: die beeld moet verband hou met Wie en hoe God in Homself is (König, 2006:102).

Christus word ook die beeld van God genoem, wat beteken dat God met sy volle wese in Hom woon (Kol. 1:19; 2:9). Christus as beeld van God is die prototipe van die ware mensheid (Fil. 3:21; Kol. 3:10; Bridger, 1995b:23). Hy is die tweede Adam. Daarom dat die Skrif die gelowige kan oproep om gelykvormig aan die beeld van Christus te

3 Die 1983-vertaling lui soos volg: “... lewe as nuwe mense wat as die beeld van God geskep is: lewe volkome volgens die wil van God en wees heilig". 
word (Rom. 8:29; 2 Kor. 3:18). Om aan Christus se beeld te konformeer, beteken 'n gerigtheid van konkrete liefdesdade teenoor jou naaste. In die Pauliniese literatuur word die beeld van God op Jesus oorgedra. In werklikheid is dit nie nodig om 'n onderskeid tussen die beeld van God en die beeld van Christus te tref nie (König, 2001:102). As die perfekte beeld van God, is Christus die voor-beeld van ware humaniteit of van menswaardige optrede. Dit beteken ' $n$ lewe van liefde (wat genesing insluit, Matt. 14:14), diens, vergifnis en nederigheid (kyk Fil. 2:5; Kol. 3:13; Ef. 4:32; 5:2; Joh. 13:14, 15). Christus se beeld beteken dat Hy vir ander lewe (Brown, 1995:242). Hierdie beeld van Christus, moet gereflekteer word en vorm die imago Christi (Bridger, 1995b:23). Die mens wat die voorbeeld van Christus navolg, dus die imago Christi word, vorm die ware beeld van God (O'Mathúna, 1995:204). Omdat ons bedoel is om God se beeld te wees, sal ons uit ons kennis oor Hom kan aflei hoe ons behoort te wees (König, 2001:105; vgl. ook O’Mathúna, 1995:202).

Ons kan bogenoemde argumentasie soos volg saamvat (König, 2006:62):

Ons is die beeld van God as ons in ons hele lewe soos Hy leef, as ons lewe aan Hom herinner, as ons waardesisteem Syne verteenwoordig. Daar moet ooreenkoms wees tussen Hom en ons.

Wat beteken die gegewe vir die bioetiek dat die mens die beeld van God is?

\subsubsection{Menswaardigheid as gegewe status}

Beeldskap dui op die unieke en verhewe status (of belangrikheid) van die mens (Østnor et al., 1995:13, 30; Sulmasy, 2008:484). Vir die Christelike etiek rus die oneindige waarde van elke mens in die feit dat hy/sy na die beeld van God geskape is (Grogan, 1995:477; O'Mathúna, 1995:200, 202; Tada \& Cameron, 2006:51; Vorster, 2008:122; Gelernter, 2008:395-396). 4 "Die mens, en dit geld vir alle mense, het 'n besondere waarde én waardigheid", skryf König (2001:140). Hierdie status of waarde word versterk deur die feit dat nét die mens na die beeld van die waardevolle God geskape is (Imago Dei). In hierdie hiërargie van bestaan vorm God aksiomaties

$4 \quad$ "The fulfillment of this duty implies courageous opposition to all those practices which result in grave and unjust discrimination against unborn human beings, who have the dignity of a person, created like others in the image of God." (RKK, 2008.) 
die hoogste vorm van bestaan en waardigheid. God vertoon waardigheid (Higginson, 1995:98). Daarom dat Hy in Openbaring 4:11 as dié waardevolle (a kio") besing word (vgl. ook Hebr. 3:3). Hy is die Absolute in waardigheid. As God absolute waardigheid is en die mens sy beeld, dan besit die mens afgeleide, maar definitiewe waarde. Daarom dat die volgende in Psalm 8:6 van die mens gelees word (1953-vertaling): " $U$ het hom 'n weinig minder gemaak as 'n goddelike wese en hom met eer en heerlikheid gekroon." Volgens Vorster (2008:122) word in hierdie Skrifgedeelte 'n treffende voorbeeld van die mens se waarde gevind. 5 Esterhuyse (2009:48) stel dit soos volg: "Dis bes moontlik dat die storieverteller dié woorde (mens as beeld van God - ALR) gekies het om nie bloot 'n antropomorfe voorstelling van die baie abstrakte begrip 'god' te gee nie, maar ook die mag en verhewe posisie van die mens in die skepping aan te dui."

Die realiteit dat die Seun van God mens geword het en as mens heerlikheid (doxan) vertoon, bevestig die waardigheid van die mens (Joh. 1:14). Die mens besit besondere waarde, want hulle deel aan die goddelike natuur (2 Pet. 1:4; RKK, 2008). Dit is ook belangrik om op te merk dat Christus se lewe en kruisdood as vernederende omstandighede (onmenswaardige omstandighede) nie sy inherente waardigheid aangetas het nie. Hy is steeds as (beeld van) God aanbid, ten spyte van die feit dat Hy 'n onwaardige kriminele dood aan die kruis gesterf het (Meileander, 2008b:261-262). Die mens behou sy waardigheid ten spyte van sy omstandighede. Die waarde van mense word verder ondersteun in God se misterieuse verkiesing van die mens alleen om sy liefde aan te bewys (Kraynak, 2008:74; Kass, 2008:323-324). Volgens Kass (2008:306-315) word die waardigheid van die mens deur sy voortreflikheid (excellence) en besondere prestasies in die geskiedenis bevestig en geïllustreer. Dit moet net genoem word dat die waarde van die mens nie afgelei word uit die inherente goedheid van die mens nie, maar dit is ' $n$ waarde wat in die verbinding met God aan die mens toegeken is (Peters, 1996: 53). God gee waardigheid juis as gevolg van die sonde (Vorster, 2008:123).

Indien die mens dan besondere waarde het, en die mens as beeld soos God is en soos Hy moet wees, dan is die logiese dat die mens menswaardig moet optree teenoor God, homself, sy naaste en die skepping (Sulmasy, 2008:482-483). "Dignity is a status that God 
awards the human, and therefore the human should live according to his status and treat others according to their status", skryf Vorster (2007:20). Daarom gee God aan die mens bepaalde pligte. Pligte erken menswaardigheid (Heyns, 1982:388; Gelernter, 2008:399). Respek begin by die erkenning van die gegewe dat die mens menswaardig is en daarom kan die ad rem afleiding gemaak word dat respek uit die waarheid van menswaardigheid vloei (vgl. Sulmasy, 2008:484, 497). Omdat die mens menswaardig is, moet hy God, homself en ander mense respekteer (RKK, 2008). Hierdie afleiding is baie belangrik vir die bioetiek. Die mens as beeld van God moet ook met menswaardigheid handel. Die mens as beeld van God het dus die taak om voor die wêreld (coram mundo) van die menswaardigheid van die mens te getuig (Østnor et al., 1995:27).

Dit is tersaaklik om hier kortliks te verwys na die feit dat sommige individue daarvan oortuig is dat die mens sy menswaardigheid na die sondeval (Gen. 3) verloor het en dus geen waarde meer het nie. Die implikasie is dat die begrip menswaardigheid irrelevant vir die bioetiek is. Hierteenoor kan vermeld word dat alhoewel die beeldskap van die mens na die sondeval aangetas is, die mens nie totaal die beeld van God verloor het nie. Dit word bevestig deur die feit dat in die verhaal van Noag, na die sondeval, die beeldskap van die mens herbevestig word (Kraynak, 2008:75; Gen. 9:4). Die sekerheid dat die mens nog steeds beeld van God is, word in die Nuwe Testament bevestig (vgl. 1 Kor. 11:7; Jak. 3:9; Grogan, 1995:477; König, 2001:101). Laasgenoemde neem nie die gegewe feit weg dat God se beeld in die mens wel deur die sonde versteur is nie. Die mens wat God se liefde moet reflekteer, kan nou ook haat. Die mens se ooreenkoms (verhouding) met God en sy naaste is nou verdraai. In plaas daarvan om die beeld van God te reflekteer en die besondere ooreenkoms uit te straal, wil die mens eerder self die oorspronklike beeld, God self, word (vgl. Gen. 3:5). Omdat die mens se beeldskap nie in besondere menslike eienskappe gefundeer is nie, maar 'n status is wat aan die mens toegesê is, kan 'n mens nie die beeld verloor nie.

Vervolgens gaan gekyk word wat die bioetiek as menswaardige handelinge deur die mens en teenoor die mens verstaan.

\subsection{Menswaardigheid toegepas in die bioetiek}

\subsubsection{Menswaardigheid en heerskappy}

Menswaardigheid impliseer in hierdie konteks die reg (plig) tot gesondheidsorg. Die volgende betekenis van die mens as beeld van 
God word gevind in die feit dat die Bybel beeldskap met heerskappy (dominion) verbind (O'Mathúna, 1995:200). In Genesis 1:26 staan: "Toe het God gesê: 'Kom Ons maak die mens as ons verteenwoordiger, ons beeld, sodat hy kan heers oor die vis in die see, die voëls in die lug, die mak diere, die wilde diere en al die diere wat op die aarde kruip" (vgl. ook Gen. 9:4; Ps. 8:7).

In sy heerskappy vertoon die mens die beeld van God wat oor alles regeer (Douma, 1997:44). Soos God absolute heerskappy oor die skepping besit, so besit die mens, as beeld van God, beperkte heerskappy oor die skepping (Grogan, 1995:476; Kraynak, 2008:75). Hierdie heerskappy vind sy uitdrukking in besondere menslike aktiwiteite of dade wat die mens en die natuur as objek het.

It is clear from the context that the human being must exercise his dominion over the earth in responsibility to God's sovereign rule and in a way that will enhance the earth and all its creatures ... The life of the human being is inextricably linked to the existence of the animal and plant realm. (Vorster, 2007:3940.)

Kass (2008:324) maak ook die verbinding tussen die beeldskap, heerskappy en bioetiek. In Genesis 1 word opgemerk dat God skeppend (makend) besig is en dat hy in besonder sorg dra dat dit wat goed en perfek is tot stand gebring word (RKK, 2008; Gen. 1:31). God het die skepping goed gemaak (Holmes, 1995:270). Die afleiding is dat God dit wat goed en perfek is, bewerkstellig. Hierin vind die beeldskap van die mens sy uitdrukking. Die belang vir die bioetiek bestaan daarin dat die mens ook dit wat goed is, tot stand moet bring.

'n Besondere manier om dit wat goed is te bewerk, is deur genesing. Die unieke en opmerklike verbinding tussen beeldskap en genesing word juis in Christus bevestig. Christus, as God se beeld, verteenwoordig God se koninklike heerskappy op aarde (Vorster, 2007:44). Daar is reeds daarop gewys dat menswaardige lewe die navolging van Christus beteken. Omdat ons die beeld van Christus is, impliseer dit dat dieselfde werk wat Hy doen, ons ook sal doen (König, 2006:102-103). Vir die bioetiek hou dit die volgende in: Christus het nie alleen sonde aan die kruis kom bestry nie, maar ook die gevolge van die sonde, naamlik siekte. Volgens Peters (2007:66-67) het Christus ons nie alleen oor genesing geleer nie, maar dit ook vir ons gedemonstreer. ' $n$ Voorbeeld van eersgenoemde is te vind in die gelykenis van die barmhartige Samaritaan (Luk. 10:30-37). In dié gelykenis definieer Christus naasteliefde (v. 27) as die innige jam- 
mer kry (v. 33) van halfdooie mense (v. 30) deur hulle tot beterskap en gesondheid te help (v. 34-35). Hierdie gelykenis dien ook as motivering en roeping om te genees. Wat die demonstrering betref, moet dit die etikus opval dat Jesus Christus siek mense genees en dooies opgewek het (Cook, 1995:436). Dit vorm 'n integrale en wesenlike deel van sy werk op aarde (Hurding, 1995:431; König, 2001:185). Christus het byvoorbeeld die skoonmoeder van Petrus van koors genees (Luk. 4:49), gestremdes (Mark. 2; Joh. 5) en dowes (Mark. 7:5) genees en Lasarus (Joh. 11:33) uit die dood opgewek (Hurding, 1995:431). "Jesus was a healer", skryf Peters (2007:66; König, 2001:185). Volgens Douma (1997:49) moet 'n mens, as beeld van God, aan die feit dat Christus mense gesond maak die vrymoedigheid en reg ontleen om werklik pogings aan te wend om siekte te genees en te voorkom (vgl. ook Atkinson, 1995:89; Nilsson \& Kvist, 1995:91). Christus stuur dus sy dissipels uit om siek mense gesond te maak (Matt. 10:1; Østnor et al., 1995:26). Genesing deur Christus kan nie anders verstaan word as die beoefening van liefde nie (Matt. 14:14). Om te genees, is in werklikheid 'n vorm van naasteliefde (vgl. De Bruyn, 1993:158; Peters, 2007:62-63). Daarom sê Sulmasy (2008:478) “... human dignity is the foundation of health care". In die lig van bogenoemde beredenering, kan met (Sulmasy, 2008:487) saamgestem word dat "... the fundamental reason one provides health care is out of respect for intrinsic dignity". Wie nie genees nie en wie nie genees wil word nie, tree onmenswaardig op. Onnodig om te sê dat wetenskaplikes en geneeshere in die genesingsproses menswaardigheid moet respekteer (Østnor et al., 1995:28).

Binne die bioetiek moet tegnieke wat infertiliteit kan herstel, ondersteun word. 6 Genesing impliseer nie net gesond maak nie, maar sluit ook die versorging van die hulpeloses in (Luk. 10). Laasgenoemde beteken dat 'n mens toegelaat moet word om te sterf. Hiermee saam moet navorsing en investering in die voorkoming van infertiliteit ernstig aangemoedig word (RKK, 2008). Stamselnavorsing en terapie waarin die menslike embrio gerespekteer word (vgl. 3.2.4), moet ook ernstig nagevors en ontwikkel word. Alhoewel die volgende tegnieke nie genesing bewerk nie, kan dit (binne sekere riglyne) as menswaardige bioetiese handelinge beskou word: homoloë kunsmatige inseminasie, in vitro-bevrugting, kloning, embrionale diagnostiek, intrasitoplasmiese sperminplasing en die bevriesing van

6 Dit sluit onder andere hormonale behandeling in, asook operasies wat endometriose behandel en geblokte Fallopiusbuise herstel. 
sperm- en eierselle vir latere gebruik. In die lig van bogenoemde beredenering kan eutanasie en geassisteerde selfmoord as onmenswaardige handelinge gesien word.

\subsubsection{Menswaardigheid en psigosomatiese eenheid}

Menswaardigheid impliseer die reg (en plig) om as totale mens (as eenheid van liggaam en siel) gesien en behandel te word, asook om self so op te tree. Word die beeld van God net aan sekere tipe mense verbind, byvoorbeeld net aan gesonde mense? Anders gestel: Kan net sekere mense dus as menswaardig beskou word? In die verlede is op verskeie maniere gepoog om die beeldskap van die mens net met fisiese en psigiese eienskappe te verbind (O'Mathúna, 1995:200; Vorster, 2007:19), naamlik die rede, taal, vrye wil, 'n regop postuur, ontsterflikheid, die vermoë om lief te hê, heiligheid en geregtigheid. Baie moderne wetenskaplikes binne die bioetiek wil die waarde van die mens met sy brein of rasionale vermoë verbind (Dennet, 2008:45). Pogings om die beeld van die mens slegs in rasionele terme te verstaan, het sy oorsprong in 'n dualistiese verstaan van die mens (Bridger, 1995b:23). Hierdie vorm van dualisme, met die klem op die rasionalisme, het genadelose gevolge meegebring. Dit het beteken dat die mens maklik in twee dele ingedeel word, naamlik die belangrike deel, die rasionele as beeld (die siel), en die res (die liggaam) as die onbelangrike deel van die mens (König, 2006:60). Die implikasie van bogenoemde beredenering vir die bioetiek is daarin geleë dat mense wat byvoorbeeld nog nie oor volle rasionele vermoëns beskik nie, soos embrio's en fetusse, nie as menswaardig beskou kan word nie. Dieselfde geld ook vir mense wat om die een of ander rede hulle rasionele vermoë verloor het soos in die geval van breinbeserings of bejaarde persone. Hulle sou dan hulle menswaardigheid in die loop van die lewe verloor het. Wanneer mense nie as menswaardig beskou word nie, word daar gewoonlik teen hulle gediskrimineer. Vorster (2008:125) sê in dié verband: "When the others are regarded as people without inherent human dignity, it becomes easy to discriminate and oppress."

Hierteenoor noem Müller (1989:5) dat Genesis 1:27 daarop dui dat God die mens (nie die siel apart nie) na sy beeld geskape het as hy sê: "Dit is ook ... duidelik dat die skrywer van Gen. 1 geen onderskeid tref tussen siel en liggaam nie. Die hele mens in psigosomatiese sin, is geskape na Gods beeld." Die liggaamlike (stoflike) Adam moet eers sy psige (Gees van God) ontvang voor hy as mens lewe en Eva word uit die psigosomatiese Adam geskep (Bridger, 1995b:24; Gen. 2:7, 21-24). In aansluiting by Müller (1989:5), is ook König (2006:60) van oordeel dat daar nêrens in die Bybel die indruk 
geskep word dat iets in die mens, dit wil sê net 'n deel van die mens, die beeld van God is nie. Die skeppingsnarratief beklemtoon die waarheid dat die mens na die beeld van God geskape is (Gen. 1:26$27 ; 2: 21-24)$. Hieruit kan die afleiding gemaak word dat alle mense en die hele mens, na die beeld van God geskape is (O'Mathúna, 1995:202-203; Østnor et al., 1995:30; Meilaender, 2008b:264). Dit geld in sowel die Ou as Nuwe Testament (Ps. 8:5-6; Ef. 4:24; 1 Kor. 7:11; Jak. 3:9). In die lig hiervan sê Kraynak (2008:74-78):

The Bible even uses the image of God (kurisvering - ALR) to avoid designating a set of qualities as the essential attributes of man, thereby precluding a Christian theory of human nature in the strict sense. Instead of focusing on attributes, the Bible presents man in terms of his relations to God.

Die Rooms-Katolieke Kerk (RKK, 2008) sê die volgende in dié verband:

In the face of this manipulation of the human being in his or her embryonic state, it needs to be repeated that God's love does not differentiate between the newly conceived infant still in his or her mother's womb and the child or young person, or the adult and the elderly person. God does not distinguish between them because he sees an impression of his own image and likeness (Gen 1:26) in each one.

Hierin vorm die mens ook die beeld van God Drie-enig wat in sy eenheid en verskeidenheid as Vader, Seun en Heilige Gees waardig is. Daar is totale gelykheid binne die Drie-eenheid. Nie een van die Persone is minder of meer God nie, of minder of meer belangrik nie (Heyns, 1978:49). Alhoewel hierdie gelykheid bedoel word in die verhouding van die Persone tot mekaar (Brown, 1995:241, 243), kan afgelei word dat met gelyk ook bedoel word dat nie een deel van God, of die Drie-Persone, meer of minder waarde het nie. "In this social model Father, Son and Spirit are co-equal in status ... In all these, the life of the Trinity is to be imaged and shared." (Bridger, 1995a:353.) Om hierdie rede noem Brown (1995:241) die Drie-eenheid die goddelike prototipe van totale gelykheid. Die geestelike in die Vader en Gees is nie meer van waarde as die fisiese in Jesus nie. Hiermee saam bestaan die Een ook nie sonder die Ander nie. Dit het implikasie vir die mens as psigosomatiese eenheid, wat tegelyk ook sy beeld is. Waar die fisiese (liggaam) is, daar is ook die geestelike (siel), en waar daar siel is, is daar liggaam. Dit beteken waar daar "net" menslike liggaam is, is daar beeld, en waar daar beeld is, is daar waardigheid wat gerespekteer moet word. Die besondere waarde van sodanige beredenering is dat die mens in sy 
totale psigosomatiese bestaan, van konsepsie tot die dood, waarde het. Die konklusie van hierdie bespreking vir die bioetiek is daarin geleë dat embrio's, fetusse, bejaardes en gestremdes nie minder mens is nie, en as menswaardig beskou en so behandel moet word (vgl. ook Sulmasy, 2008:488-499). Om 'n embrio of 'n gestremde persoon te reduseer tot bloot die fisiese en daarom dood te maak, tas sy menswaardigheid aan.

Die fait accompli dat die mens as beeld van God nie aan 'n bepaalde fisiese en psigiese eienskap van die mens verbind word nie, word bevestig deur die feit dat die res van die Skrif leer dat 'n mens 'n psigosomatiese eenheid vorm (Grogan, 1995:476). So kan die Bybel met die woorde siel (Lev. 23:30), gees (Luk. 1:37) en hart (Ps. 22:27; Rom. 1:21) eenvoudig net die menslike persoon aandui (König, 2006:315-316). Waar daar liggaam is, is daar siel, en waar daar siel is, is daar ook liggaam. Voorstanders van verskeie voortplantingstegnieke soos heteroloë inseminasie, in vitro-bevrugting met skenkergamete, surrogaatmoederskap, kloning buite die huwelik voer aan dat hierdie biotegnologie nie die beeld, menswaardigheid en welsyn van die mens aantas nie, omdat dit bloot die fisiese deel van die mens raak. Hierdie is nie 'n nuwe redenasie nie en vanuit die Skrif is dit ook nie 'n oortuigende argument nie. Dit is deel van die gnostiese antropologie waar die siel of geestelike deel van mense belangriker as die fisiese en liggaamlike aspek beskou is. Die gnostieke dualisme het geredeneer dat fisieke dade soos promiskue seks moreel aanvaarbaar is. Seks is fisies en liggaamlik en raak nie die geestelike of psigiese deel en welstand van die mens nie. Die holistiese natuur van die mens impliseer egter dat menslike voortplanting nooit net tot biologiese aktiwiteite gedegradeer mag word nie. Die instrumentele gebruik van 'n ander mens se liggaam is die blatante ontkenning en aantasting van sy mensweardigheid. In dié verband sê Meilaender (2008b:269): "Hence, to flourish as the human species, to manifest human dignity, is to live within certain limits - as creatures whose life is an integrated whole of body, mind, will, and spirit."

\subsubsection{Menswaardigheid en antropogenese}

Menswaardigheid beteken die reg (en plig) om binne die huwelik, met genetiese materiaal van binne die huwelik verwek te word. 'n Volgende betekenis van die mens as beeld van God word gevind in die saambinding daarvan met menslike seksualiteit en voortplanting (Gen. 1:26-29; 2:21-24; 5:1-3; 9:5-7). In Genesis 1:27-28 staan: "God het die mens geskep as sy verteenwoordiger, as beeld van God het Hy die mens geskep, man en vrou het Hy hulle geskep. Toe 
het God hulle geseën en vir hulle gesê: 'Wees vrugbaar, word baie, bewoon die aarde en bewerk dit"' en in Genesis 2:24 word die volgende gevind: "Daarom sal 'n man sy vader en moeder verlaat en saam met sy vrou lewe, en hulle sal een word." Deur hierdie samebinding word besondere waarde aan menslike voortplanting geheg en sonder twyfel met menswaardigheid verbind (Kass, 2008:327; Kraynak, 2008:75-76). Daar is menswaardige vorms van seksualiteit en voortplanting en daar is ook vorms wat menswaardigheid aantas. 'n Mens is nie net menswaardig nie, maar jy moet ook menswaardig optree.

Uit Genesis 1:27-28, asook Genesis 2:24 kan die afleiding gemaak word dat seksualiteit en voortplanting eksklusief aan die een-manen-een-vrouverhouding gekoppel word. Eenwording of die geslagsdaad (1 Kor. 6:16), waardeur vrugbaarheid bewerk word, word aan die een-man-een-vrouverhouding binne die huwelik verbind. Christus bevestig in Matteus 19:3-7 die waarheid van Genesis 1 en 2 dat seksualiteit (en dus voortplanting) uitsluitend tot die skeppingsorde van die huwelik van een man en een vrou behoort. Jesus noem dat net "hulle twee" (oij duv) sal een word. Eksklusiwiteit word bevestig deur die waarheid dat Jesus aandui dat owerspel ( $p$ or nei a) sonde is (Matt. 19:9). Teen die agtergrond van die eksklusiwiteit van die huwelik, maak Paulus in 1 Korintiërs 7:4 die opmerking dat die liggaam (s wmat o") van die man aan die vrou behoort en vice versa. Hiermee saam moet in ag geneem word dat geslagsgemeenskap (eenwording) en dus voortplanting aan die "man en vrou" gesamentlik in die huwelik gegee word (vgl. Gen. 2:24; Matt. 19:5). Dit beteken dat God dit so bedoel het dat voortplanting deur "twee" in die huwelik bewerk moet word. Dit is die skeppingsnorm dat bevrugting deur man en vrou, dus twee, bewerk moet word. "Twee moet een word." Die verkryging van kinders is verbind aan twee ouers, naamlik man en vrou, vader en moeder. Die Bybel dui op 'n bigenetiese bydrae met die oog op voortplanting. In hierdie lyn van denke kan beweer word dat alle "middele en materiaal" wat vir voortplanting gebruik word, soos die penis (semen), vagina (eierselle) en baarmoeder eksklusief tot die huwelik behoort.

Verskeie teoloë is van mening dat die beeld van God gereflekteer word in die verhouding van man en vrou (Grogan, 1995:476; Meilaender, 1995:76). Die beeld bestaan daarin dat die mens, soos God, meervoudig bestaan. "Theologically and historically the Trinity has been held to function as a model of persons-in-relationship" (Bridger, 1995a:353). Die mens bestaan as 'n twee-eenheid en God as 'n Drie-eenheid. God sê immers, laat ons die mens maak na ons 
beeld. Soos God in die verhouding van die Drie-eenheid lewe, so lewe die mens in die verhouding van die tweeheid. "The relationship between man and woman is thus placed on the same basis as the relationship within God himself." (Vorster, 2007:40.) Die interne verhouding van God, naamlik Vader, Seun en Gees, spesifiseer die beeld van God in die mens (Brown, 1995:241).

Die feit dat die beeld van God met man en vrou verbind word, en daarmee saam ook seksualiteit, kan die afleiding gemaak word dat die beeld van God ook met voortplanting verbind moet word. In sy bespreking van Genesis 1:27 sê Bridger (1995b:26-27): "Adam and Eve are created as complementary sexual beings who together reflect the creative image of God ... The sexual-relational nature of the imago is thus underlined." Alhoewel die bioetiek nie sy fokus is nie, erken Vorster (2007:21) ook dat daar 'n band tussen die mens as beeld van God (dus menswaardigheid) en voorplanting bestaan. In sy bespreking van menslike seksualiteit en menswaardigheid poneer Vorster (2007:70) die volgende: "Sexual identity and human dignity are closely related to each other." 7 Dit beteken nie dat die seksdaad die beeld van God verteenwoordig nie, maar wel die waarheid dat die mens, soos God, mense skep (Meilaender, 1995: 73). 8 Die argument dat die beeld ook met voortplanting verbind word, word versterk deur die feit dat aan man en vrou, as beelddraers, direk die opdrag gee word om vrugbaar te wees. God Drieenig bring skeppend mense voort. Daar moet ook met erns kennis geneem word van die feit dat die Drie-enige God die mens geskep het en nie die enkelvoudige God van die deïsme nie (Bridger, 1995b:22): “... The composite picture of humanity that emerges is one in which human beings individually and corporately are the creation of Father, Son and Spirit acting together. This has profound implications for the social nature of humanity." (Vgl. Gen. 1:2-3; 2:7; Joh. 1.)

$7 \quad$ "Though sex is a private act of intimacy that has direct consequences for our personal dignity, it also has an undeniable influence on the dignity of the society as a whole. The social need for stable human relationships and sound procreational customs, as well as the threat of unwanted pregnancies, sexual abuse, sexual diseases and so forth are but a few examples of the social implications of sexual behaviour." (Vorster, 2007:70.)

8 "To take up this task (of procreating - ALR) is to align oneself with God's creative work, with the blessing embedded in the created order." (Meilaender, 1995:73.) 
Anders gesê, soos God die eerste mensepaar (die huwelik) as sy beelddraers geskep het, so kry die mens die opdrag om met die skepping van beelddraers voort te gaan. God gebruik niemand van buite sy Drie-enige verhouding om mense te skep nie en hiermee saam is ook nie net een Persoon by die skepping van die mense betrokke nie. Duidelik staan daar: "Laat ons mense skep." Soos God die Vader deur Christus en die Gees skep, so mag die man nie sonder sy vrou en die vrou sonder haar man kinders verwek nie. Soos die ruimte van die Drie-eenheid die ruimte is waarbinne geskep word, so is die huwelik die terrein waarbinne voortgeplant moet word. Nooit is een van die drie Persone in die skepping van die mens uitgesluit nie. Uit bogenoemde beredenering kan die gevolgtrekking gemaak word dat voortplanting binne die huwelik deel van die skeppingsorde is. Dit beteken dat God se wil vir voorplanting die huwelik is. Beeldskap word gevind in die werklikheid dat God die een man en een vrou, dus die huwelik, die opdrag gee om voort te plant (Kraynak, 2008:76). Hiermee saam het God Drie-enig wat liefde is, binne sy Drie-enige liefdesverhouding die mens geskep. "In this social model Father, Son and Spirit ... exist ... in mutual love ... In all these, the life of the Trinity is to be imaged and shared" (Bridger, 1995a:353). Die mens as beeld van God word geroep om hierdie trinitariese skeppingsliefde van God, in sy verwekking van kinders, te reflekteer (RKK, 2008). Daarom word man en vrou wat lief is vir mekaar, in die huwelik geroep om kinders te verwek (Ef. 5:25-33; Hooglied; Rheeder, 1999:386-389; Meilaender, 2008b: 269). In die lig van bogenoemde beredenering maak dit sin as die Amerikaanse President's Council on Bioethics praat van "the dignity of human procreation" (vgl. Meilaender, 2008b:268).

Volgens (Kraynak, 2008:81) is slegs daardie biotegnologie geregverdig wat binne die grense van menswaardigheid beweeg, deur menswaardigheid te respekteer. In die lig van bogenoemde beredenering sou die volgende op onmenswaardige etiese praktyke neerkom (Kraynak, 2008:81): heteroloë inseminasie, in vitro-bevrugting met gamete van buite die huwelik, surrogaatmoederskap, kloning met genetiese materiaal van buite die huwelik en alle pogings om menslike en dierlike materiaal om watter rede ook al, reproduktief te vermeng (vgl. ook Kass, 2008:298). Intrasitoplasmiese sperm inplasing waar materiaal van binne die huwelik kom, sou ook eties aanvaarbaar wees. Genetiese manipulasie waar genetiese materiaal en kombinasies van buite die huwelik kom, dus 'n eugenetiese en nie 'n genesende gebruik nie, sou op onmenswaardige voortplanting dui. Die wese van voortplanting is dat kinders ontvang word 
en dat die ouers se keuse in hulle gene en nie in hulle wil lê nie (Ps. 127:3; Rheeder, 1999:412-414).

Ten opsigte van bogenoemde bespreking moet genoem word dat die Rooms-Katolieke Kerk van die standpunt uitgaan dat dit deel van die beeldskap van die mens is dat kinders slegs deur die geslagsdaad verwek mag word (RKK, 2008). Die opmerking is reeds gemaak dat die geslagsdaad per se nie met die beeld van God verbind moet word nie, maar wel die breë gedagte dat die mens soos God mense skep. Mag die mens soms, soos by homoloë kunsmatige inseminasie, in vitro-bevrugting en kloning binne die huwelik, sonder die geslagsdaad in uitsonderlike gevalle kinders verwek? Hierop die volgende drie opmerkings: eerstens moet opgemerk word dat voortplanting nie buite die vryheid van die huwelik mag beweeg nie, en tweedens moet raakgesien word dat in die skeppingsnarratief God Drie-enig nie net op een manier en met net een middel die mens geskep het nie, maar dat hy wel Adam en Eva met verskillende "metodes" en "middels" geskep het (Gen. 2:7, 22). Vir Adam het Hy "geformeer uit die stof van die aarde" en vir Eva "gebou uit die rib van die man". Christus, as tweede Adam, is ook nie deur geslagsgemeenskap verwek nie (Luk. 2:34). Hieruit wil ons versigtig aflei dat die mens soms van die skeppingmetode (geslagsgemeenskap) en middel (gamete) mag afwyk. In die lig van hierdie beredenering sou kloning binne die huwelik, in uitsonderlike gevalle, myns insiens nie as onmenswaardige voortplanting beskou kan word nie. Identiese tweelinge dui daarop dat ooreenstemming, as uitsondering, nie die beeld van God aantas nie. In die geval is Sulmasy (2008:495) nie korrek as hy beweer dat kloning menswaardigheid aantas nie. Kloning met genetiese materiaal van buite die huwelik sou wel as onmenswaardige voortplanting beskou kan word.

$\mathrm{Na}$ die sondeval is menslike voortplanting ook van sy menswaardigheid beroof. In sy kommentaar op Genesis 1:28 skryf Wenham (1987):

Here, then, we have a clear statement of the divine purpose of marriage: positively, it is for the procreation of children; negatively, it is a rejection of the ancient oriental fertility cults. God desires his people to be fruitful. His promise makes any participation in such cults or the use of other devices to secure fertility not only redundant, but a mark of unbelief (cf. Gen. 16; 30:14-15).

In Genesis 16 word die eerste voorbeeld van voortplanting buite die skeppingsorde om gevind. Abram verwek 'n kind buite sy huwelik 
met Sarai. Voortplanting buite die huwelik word as 'n daad van ongeloof gesien. Die onmenswaardigheid van hierdie manier van voortplanting word gevind in die wyse waarop Abram, Sarai en Hagar voortplant (vorm gedeeltelike surrogaatmoederskap), maar word ook gesien in die onmenswaardige handelinge wat ná hierdie wyse van voortplanting volg: Hagar begin Sarai verag (Gen. 16: 4), Sarai voel verontreg en behandel Hagar uitermate sleg (v. 5-6), en laastens word gevind dat selfs Ismael onmenswaardige gedrag vertoon (v. 12).

\subsubsection{Menswaardigheid en lewe}

Menswaardigheid impliseer die plig om alle menslike lewe maksimaal te beskerm - dit impliseer 'n reg om te lewe (Østnor et al., 1995:31; Meilaender, 2008b:268). Die laaste betekenis van die mens as beeld, word gevind in die gegewe dat beeldskap met menslike lewe gelykgeskakel word. In Genesis 9:5-7 word die volgende gevind (1953-vertaling): "Hy wat die bloed van 'n mens vergiet, sy bloed sal deur die mens vergiet word; want God het die mens na sy beeld gemaak" (vgl. ook Jak. 3:9). Deur hierdie skakeling word sonder twyfel 'n spesiale waarde aan menslike lewe toegeken (Kraynak, 2008:75-76). God wil dat die mens, as sy beeld, lewe moet vertoon soos Hy lewe. Die onaantasbaarheid van menslike lewe en die gepaardgaande verbod teen moord is gefundeer in die feit dat die mens die beeld van God is (Holmes, 1995:268; Wright, 1995:49; Kass, 2008:325; Vorster, 2008:122, 131). Menslike lewe mag nie wederregtelik geneem word nie. Menslike lewe verdien besondere respek. Die wederregtelike doodmaak van die menslike lewe vernietig God se beeld in die mens en op dié wyse word God gespeel (Vorster, 2007:20). Die beginsel dat die mens na die beeld van God geskape is, verleen aan die embrio en fetus ' $n$ intrinsieke waarde.

Volgens O'Mathúna (1995:203) het die mens as beeld van God verreikende betekenis vir die etiek in die algemeen en die bioetiek in die besonder (vgl. ook Tada \& Cameron, 2006:103). Hoe tree God op teenoor voorgeboortelike lewe en hoe moet die mens as beelddraer teenoor voorgeboortelike lewe optree (hoe tree God op teenoor alle menslike lewe)? 'n Tema wat baie sterk in die Bybel voorkom, is die waarheid dat voorgeboortelike lewe beskerm en bewaar moet word (O'Mathúna, 1995:207; Job 10:12). Psalms 139:13 lui soos volg: "U het my gevorm, my aanmekaargeweef in die skoot van my moeder." Die Hebreeuse woord wat met "aanmekaargeweef"

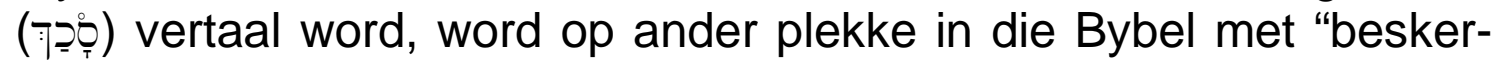


ming" of "bedekking" vertaal (vgl. Ps. 140:8; Davidson, s.a.:576; Koehler \& Baumgartner, 1958:657; O’Mathúna, 1995:207). In Psalm 139:15 word 'n soortgelyke gedagte gevind: die Hebreeuse woord (סת) wat volgens die 1953-vertaling met "in die geheim" vertaal is, kan ook met "' $n$ plek van veilige bewaring of beskerming vertaal word" (vgl. Ps. 32:7; 119:114; Jes. 16:3; Davidson, s.a.:582; O'Mathúna, 1995:207). Neem verder in ag dat Psalm 139:16 die "entiteit"

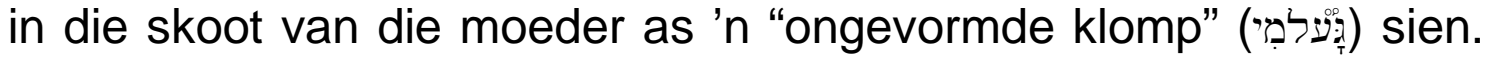
Volgens Koehler en Baumgartner (1958:185) beteken die woord גוּעלמִי "vormloos". God beskerm jou as jy nog vormloos (rond) is en glad nie menslik vertoon nie. " $U$ is my hulp van my geboorte af, reeds voor ek in die wêreld gekom het, het U my beskerm", skryf die digter in Psalm 71:6. Die Hebreeuse woord vir "beskerm" (סְָר) hou die gedagte in van "aan die lewe hou" of "sorg dat jy voortbestaan" (vgl. Ps. 119:116-117; Davidson, s.a.:578; Koehler \& Baumgartner, 1958:661). Dit is duidelik dat God die voorgeboortelike lewe wil beskerm en dit inderdaad doen. Om dood te maak, is die teenbeeld van God. As dit van voorgeboortelike lewe geld, geld dit ook sonder twyfel vir alle menslike lewe na geboorte. Die mens is 'n ontologiese eenheid van embriofase tot die sterwensfase (Rheeder, 1999:432; Sulmasy, 2008:91). Die voorafgaande beredenering het ook epistemologiese betekenis. 'n Mens hoef nie eers presies aan te toon wanneer menslike lewe begin, om korrek teenoor lewe op te tree nie (O'Mathúna, 1995:205). God is nie net die Skenker van (alle) menslike lewe nie (Van Niekerk, 2005:207), maar is ook die Beskermer van (alle) menslike lewe (Hand. 26:17, 22) en verwag dit inderdaad ook van sy kerk en sy beelddraers (Eks. 20:13; 1 Tim. 1:9).

Björnsson en Kjems (1995:43) voer aan dat dit 'n deurlopende en sterk tema in die Bybel is dat God voorkeur gee aan die swak en weerlose mens. Dit beteken dat hulle beskerm moet word (vgl. ook Christoffersen \& Mortensen, 1995:96). Die weerloses moet juis aan die lewe gehou word (Deut. 14:28-29; 26:12-13) en teen geweld (Job 24:3) en wederregtelike doodmaak beskerm word (Jer. 7:6; 22:3). God waarsku keer op keer teen kwaadwillige optrede teen die weerlose (Deut. 27:19; Kaiser, 1983:161-163). Volgens Psalm 72:13-14 is swak mense se lewe juis kosbaar (König, 1993:84). Ook Douma (1997:51) is van mening dat daar groot historiese betekenis verbonde is aan die feit dat die Here Jesus juis aan "minderwaardige" lewens soveel aandag skenk, naamlik aan die besetenes, maansiekes, verlamdes, melaatses, blindes en dowes. As gevolg van die sondeval en die gepaardgaande versteurde verhoudings word gevind dat mense op mekaar se regte begin inbreuk maak. 
Kort ná die sondeval word verneem dat Kain vir Abel doodmaak (Gen. 3:8).

In die lig van bogenoemde beredenering tree die mens self menswaardig op wanneer hy voorgeboortelike lewe menswaardig behandel deur hulle maksimaal aan die lewe te hou deur hulle teen die dood te beskerm (vgl. Meilaender, 2008b:268). Watter tegnologiese dade kan as ' $n$ aantasting van menswaardigheid beskou word? In die lig van bogenoemde beredenering kan eutanasie en geassisteerde selfmoord ook as handelinge gesien word wat menswaardigheid aantas (Sulmasy, 2008:487-488). Geassisteerde selfmoord impliseer dat 'n mens wat (terminaal) siek is, nie aktief doodgemaak mag word nie, maar dat hy toegelaat moet word om te sterf (kyk ook 3.2.1). Wat in vitro-bevrugting betref, moet die volgende ernstig oorweeg word: daar mag net soveel embrio's geskep en in 'n vrou oorgeplant word, as wat ' $n$ egpaar bereid is om mee swanger te wees. Die praktyk om soveel as moontlik embrio's oor te plaas met die hoop dat een sal heg, is 'n utilitaristiese misbruik van menslike lewe. Met ander woorde, daar mag nie oortollige embrio's geskep word nie. Verder mag geen oortollige embrio's gevries word nie, omdat dit tot die dood van baie embrio's lei. Embrio's met defekte en ongewensde genetiese inhoud mag ook nie vernietig word nie. Prenatale diagnostiek is aanvaarbaar indien die ondersoekte embrio in die moeder teruggeplaas word. Dieselfde beginsels wat vir in vitro-bevrugting geld, geld ook vir intrasitoplasmiese sperminplasing. Stamselnavorsing wat embrio's skep en dan vernietig met die oog op die skep van stamsellyne sou ook as onmenswaardige hantering van die embrio beskou kan word (Sulmasy, 2008:490-493).

\section{Slot}

In die lig van bogenoemde beredenering kan saam met (Sulmasy, 2008:498) gestem word as hy poneer:

... this conception of dignity is extraordinarily powerful in helping us to understand how we ought to proceed in answering these questions ... However, it seems clear that if this is what dignity means, then dignity is anything but a useless concept.

Dit is duidelik uit die Skrif dat die begrip menswaardigheid van groot belang vir die bioetiek is. Menswaardigheid vorm die grond waarop die etiek gevorm word, maar dit vorm ook die doel waarna gestrewe moet word. Sonder die erkenning van menswaardigheid in die bioetiek, sal die mens aan mensonwaardige diskriminasie uitgelewer wees. 


\section{Geraadpleegde bronne}

ATKINSON, D.J. 1995. Life, health and death. (In Atkinson, D.J. \& Field, D.H., eds. New dictionary of Christian ethics and pastoral theology. Downers Grove: InterVarsity. p. 87-92.)

BJÖRNSSON, B. \& KJEMS, L. 1995. In vitro fertilization: a letter to a childless couple. (In Mortensen, V., ed. Life and death: moral implications of biotechnology. Geneva: WCC. p. 41-49.)

BRIDGER, F.W. 1995a. Equality. (In Atkinson, D.J. \& Field, D.H., eds. New dictionary of Christian ethics and pastoral theology. Downers Grove: InterVarsity. p. 352-353.)

BRIDGER, F.W. 1995b. Humanity. (In Atkinson, D.J. \& Field, D.H., eds. New dictionary of Christian ethics and pastoral theology. Downers Grove: InterVarsity. p. 21-27.)

BROWN, R.G. 1995. Clones, chimeras, and the image of God: lesson from the Barthian bioethics. (In Kilner, J.F., Cameron, N.M. de S. \& Schiedermayer, D.L., eds. Bioetichs and the future of medicine: a Christian appraisal. Grand Rapids: Eerdmans. p. 238-249.)

CHRISTOFFERSEN, S.A. 1995. What is bioethics? (In Mortensen, V., ed. Life and death: moral implications of biotechnology. Geneva: WCC. p. 2-8.)

CHRISTOFFERSEN, S.A. \& MORTENSEN, V. 1995. Ethics and counseling: a letter to a fellow pastor. (In Mortensen, V., ed. Life and death: moral implications of biotechnology. Geneva: WCC. p. 94-97.)

CHURCHLAND, P.S. 2008. Human dignity for a neurophilosophical perspective. http://bioethics.gov/reports/human_dignity/human_dignity_ and_bioethics.pdf Date of access: 8 Oct. 2008.

COOK, E.D. 1995. Health and health care. (In Atkinson, D.J. \& Field, D.H., eds. New dictionary of Christian ethics and pastoral theology. Downers Grove: InterVarsity. p. 435-437.)

DAVIDSON, B. s.a. Analytical Hebrew and Chaldee lexicon. Florida: Mcdonald.

DAVIS, F.D. 2008. Human dignity and respect for persons: a historical perspective on public bioethics. Human dignity and bioethics: essays commissioned by the president's council on bioethics. http://bioethics.gov/ reports/human_dignity/human_dignity_and_bioethics.pdf Date of access: 8 Oct. 2008.

DE BRUYN, P.J. 1993. Die tien gebooie. Midrand: Varia.

DENNET, D.C. 2008. How to protect human dignity from science. http://bioethics.gov/reports/human_dignity/human_dignity_and_bioethics. pdf Date of access: 16 Nov. 2008.

DOUMA, J. 1997. Medische ethiek. Kampen: Uitgeverij van den Berg.

ESTERHUYSE, W. 2009. God en die gode van Egipte: in die spore van die onsienlike. Wellington: Lux Verbi.BM.

GELERNTER, D. 2008. The irreducibly religious character of human dignity. http://bioethics.gov/reports/human_dignity/human_dignity_and_bioethics. pdf Date of access: 8 Oct. 2008.

GROGAN, G.W. 1995. Image of God. (In Atkinson, D.J. \& Field, D.H., eds. New dictionary of Christian ethics and pastoral theology. Downers Grove: InterVarsity. p. 476-477.)

HEYNS, J.A. 1978. Dogmatiek. Pretoria: NG Kerkboekhandel.

HEYNS, J.A. 1982. Teologiese etiek. Deel 1. Pretoria: N.G. Kerkboekhandel. 
HIGGINSON, R.A. 1995. Ethics of medical care. (In Atkinson, D.J. \& Field, D.H., eds. New dictionary of Christian ethics and pastoral theology. Downers Grove: InterVarsity. p. 93-99.)

HOLMES, A.F. 1995. Creation. (In Atkinson, D.J. \& Field, D.H., eds. New dictionary of Christian ethics and pastoral theology. Downers Grove: Intervarsity. p. 268-270.)

HURDING, R.H. 1995. Healing. (In Atkinson, D.J. \& Field, D.H., eds. New dictionary of Christian ethics and pastoral theology. Downers Grove: InterVarsity. p. 431-434.)

KAISER, W.C. 1983. Towards an Old Testament ethics. Michigan: Academic Books.

KASS, L.R. 2008. Defending human dignity. http://bioethics.gov/reports/ human_dignity/human_dignity_and_bioethics.pdf Date of access: 16 Nov. 2008.

KOEHLER, L. \& BAUMGARTNER, W. 1958. Lexicon in veteris testamenti libros. Leiden: Brill.

KÖNIG, A. 1993. Menseregte: menslike mense. Gelowig nagedink. Deel 5: Oor die mens en sonde in die praktyk. Halfway House: Orion.

KÖNIG, A. 2001. Fokus op die 300 geloofsvrae wat mense die meeste vra: sleutelbegrippe van die Christelik geloof: 'n verwysingsgids vir elke huis. Wellington: Lux Verbi.BM.

KÖNIG, A. 2006. Die groot geloofswoordeboek: meer as 500 kernwoorde van die Christelike geloof maklik gemaak. Vereniging: Christelike Uitgewersmaatskappy.

KRAYNAK, R.P. 2008. Human dignity and the mystery of the human soul. http://bioethics.gov/reports/human_dignity/human_dignity_and_bioethics. pdf Date of access: 8 Oct. 2008.

MACKLIN, R. 2003. Dignity is a useless concept. http://bmj.com/cgi/content/ full/327/7429/1419 Date of access: 21 Oct. 2008.

MEILAENDER, G. 1995. Sexuallity. (In Atkinson, D.J. \& Field, D.H., eds. New dictionary of Christian ethics and pastoral theology. Downers Grove: InterVarsity. p. 71-78.)

MEILAENDER, G. 2008a. Commentary on churchland. http://bioethics.gov/ reports/human_dignity/human_dignity_and_bioethics.pdf Date of access: 8 Oct. 2008.

MEILAENDER, G. 2008b. Human dignity: exploring and explicating the council's vision. http://bioethics.gov/reports/human_dignity/human_ dignity_and_bioethics.pdf Date of access: 8 Oct. 2008.

MÜLLER, J. 1989. God se beeld en verteenwoordiger: Gen. 1:1-2:4a. (In Vos, C. \& Müller, J., reds. Geboorte en kindwees: God, mens en wêreld. Pretoria: Orion. p. 1-10.)

NILSSON, G. \& KVIST, H. 1995. Legislation on human and animal research: a letter to a parliamentarian. (In Mortensen, V., ed. Life and death: moral implications of biotechnology. Geneva: WCC. p. 86-93.)

O'MATHÚNA, D.P. 1995. The Bible and abortion: what of the "Image of God"? (In Kilner, J.F., Cameron, N.M. de S. \& Schiedermayer, D.L., eds. Bioetichs and the future of medicine: a Christian appraisal. Grand Rapids: Eerdmans. p. 199-211.) 
ØSTNOR, L., HALLAMAA, J., ANDERSON, S., BJÖRNSSON, S.V., NILSSON, G. \& THUNBERG, L. 1995. The Lutheran approach to bioethics. (In Mortensen, V., ed. Life and death: moral implications of biotechnology. Geneva: WCC. p. 9-34.)

PETERS, T. 1996. For the love of children: genetic technology and the future of the family. Louisville: John Knox.

PETERS, T. 2007. The stemcell debate. Minneapolis: Fortress.

RHEEDER, A.L. 1999. Selektiewe voortplanting by die mens: 'n teologies-etiese RKK studie. Potchefstroom: PU vir CHO. (Th.D.-proefskrif.)

kyk ROOMS-KATOLIEKE KERK

ROOMS-KATOLIEKE KERK. 2008. Congregation for the doctrine of faith: instruction dignitas personae on certain bioethical questions. http://www.vatican.va/roman_curia/congregations/cfaithe/documents/rc_ con_cfaith_doc_2008/208_dignitas-personae_en.html

SCHULMAN, A. 2008. Bioethics and the question of human dignity: human dignity and bioethics: essays commissioned by the President's Council on Bioethics. http://bioethics.gov/ reports/human_dignity/ human_ dignity_ and_bioethics.pdf Date of access: 8 Oct. 2008.

SHULTZINNER, D. 2003. Human dignity: functions and meanings. http://www.bepress.com/gj/topics/vol3/iss3/art3/ Date of access: 28 Oct. 2008.

SULMASY, D.P. 2008. Dignity and bioethics: history, theory, and selected applications. http://bioethics.gov/ reports/human_dignity/ human_dignity_ and_bioethics.pdf Date of access: 8 Oct. 2008.

TADA, J.E. \& CAMERON, M.DE.S. 2006. How to be a Christian in a brave new world. Grand Rapids: Zondervan.

UNESCO. 2005. United Nations Educational, Scientific and Cultural Organization. http://portal.unesco.org/en/ev.php-URL_ID=31058\&URL_ DO=DO_TOPIC\& URL_SECTION=201.html Date of access: 28 Oct. 2008.

VAN NIEKERK, A.A. 2005. Geloof sonder sekerhede: besinning vir eietydse gelowiges. Wellington: Lux Verbi.BM.

VAN WYK, J.H. 1991. Moraliteit en verantwoordelikheid: opstelle oor politieke etiek. Potchefstroom: PU vir CHO. (Wetenskaplike bydrae van die PU vir CHO. Reeks A: Geesteswetenskappe, nr. 77.)

VORSTER, J.M. 2008. The challenge of contemporary religious fundamentalism. Pretoria: Thabang.

VORSTER, N. 2007. Restoring human dignity in South Africa: essays in Christian anthropology for a new dispensation. Potchefstroom: Potchefstroomse Teologiese Publikasies.

WENHAM, G.J. 1987. Genesis 1-15. Dallas: Word Books. (Word Biblical commentary, vol. 1.) [CD]

WRIGHT, C.J.W. 1995. Old Testament and ethics. (In Atkinson, D.J. \& Field, D.H., eds. New dictionary of Christian ethics and pastoral theology. Downers Grove: InterVarsity. p. 48-56.) 


\section{Kernbegrippe:}

beeld van God

bioetiek

menswaardigheid

voortplanting

\section{Key concepts:}

\section{bioethics}

human dignity

image of God

procreation 